\title{
Harvestmen (Arachnida: Opiliones) in Estonia: results of the Estonian Malaise Trap Project
}

\author{
Kristiina Tomasson, Toomas Tammaru \& Olavi Kurina
}

Tomasson, K., Tammru, T. \& Kurina, O. 2014: Harvestmen (Arachnida: Opiliones) in Estonia: results of the Estonian Malaise Trap Project. — Entomol. Fennica 25: 142-156.

The species composition of Estonian harvestmen (Opiliones) was revised based on a critical review of published data and examination of the material from the Estonian Malaise Trap Project (EMTP), which is briefly introduced. Four years of collecting (from 2008 to 2011) with "Czech type" Malaise traps from 15 localities throughout Estonia resulted in 4,102 specimens of 9 species. Two of them, Lophopilio palpinalis (Herbst, 1799) and Leiobunum tisciae (Avram, 1968), were found from Estonia for the first time. Combined with reliable published data, the number of harvestmen species known from Estonia is now set at 12 . Distribution and habitat preferences of harvestmen in Estonia were examined subjecting the Malaise trapping data to a quantitative analysis using environmental variables recorded for each trap location. Only tree layer density (i.e. the presence of forest as such) was identified as a significant predictor of harvestmen abundance and diversity which indicates a low degree of habitat specificity in boreo-nemoral harvestmen.

K. Tomasson \& O. Kurina, Institute of Agricultural and Environmental Sciences, Estonian University of Life Sciences, Kreutzwaldi 5D, 51014 Tartu, Estonia; Corresponding author's e-mail: kristiina.tomasson@gmail.com

T. Tammaru, Department of Zoology, Institute of Ecology and Earth Sciences, University of Tartu, Vanemuise 46, 51014 Tartu, Estonia

Received 16 January 2014, accepted 3 March 2014

\section{Introduction}

Harvestmen (Opiliones), with more than 6,500 known species worldwide (Kury 2011), constitute one out of the 11 extant orders of arachnids (Arachnida). About 110 species inhabit Central and Northern Europe (Martens 1978), with just 27 species known to reach the Nordic countries (Stol 2007, Uddström et al. 2013). In spite of the relatively modest diversity, harvestmen, typically being abundant arthropod predators, should play an important role in ecosystems of these regions
(Hillyard 2005). The diet of harvestmen has not been thoroughly and systematically studied but the knowledge accumulated so far shows it to consist mainly of small soft-skinned invertebrates (Acosta \& Machado 2007). Nevertheless, there are records on harvestmen preying upon moths (e.g. Tanhuanpää et al. 2003) as well as ingesting plant matter, fruit juices, fungi and dead organic matter (Acosta \& Machado 2007). This makes them an exceptionally omnivorous clade among other Arachnids. Most European harvestmen have an annual life cycle: typically, eggs are 


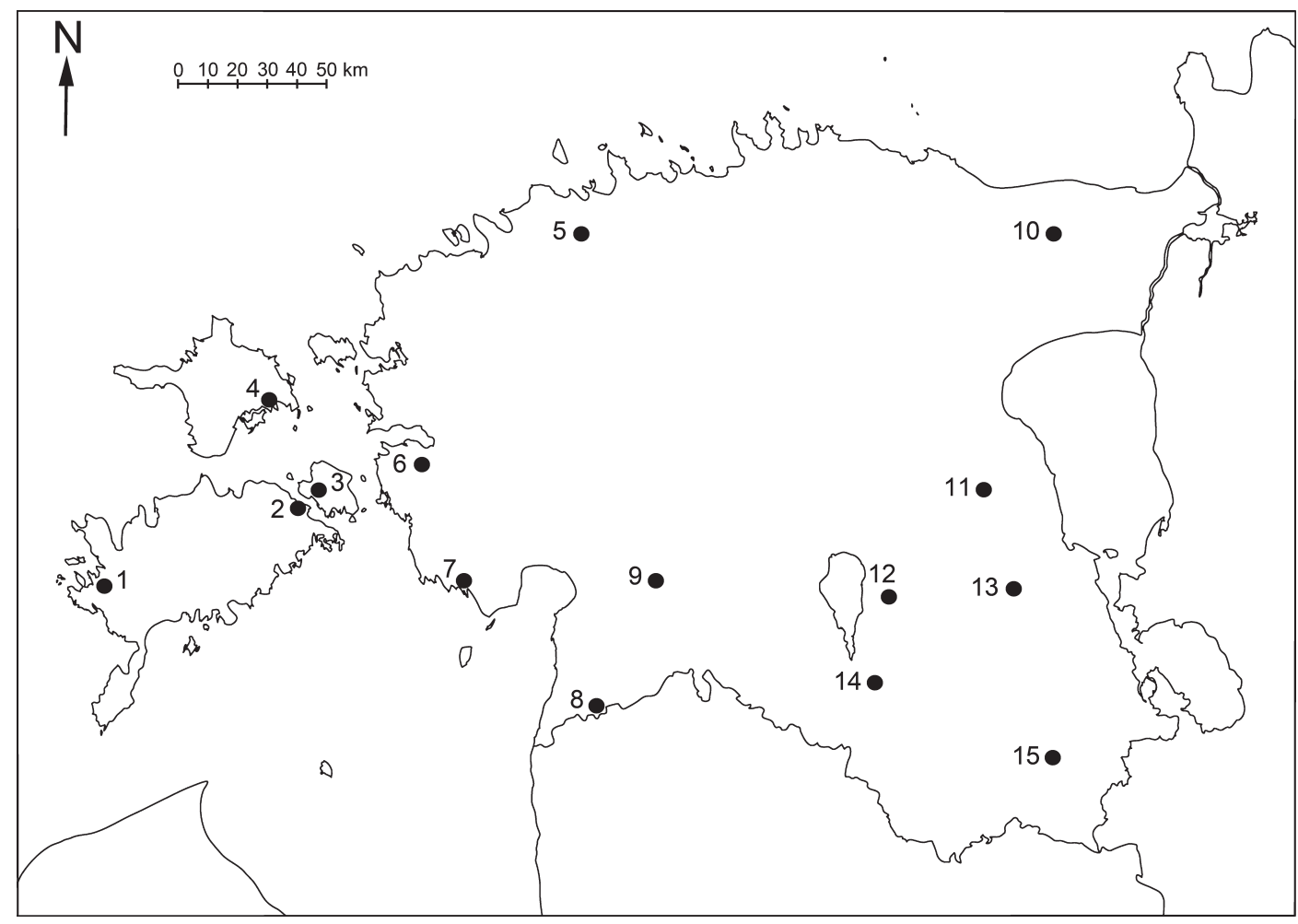

Fig. 1. Sampling localities of the Estonian Malaise Trap Project. See Table 1 for comments.

laid in late summer or autumn and the larvae hatch in the spring, passing numerous nymphal stages before reaching maturity. A few species (e.g. Rilaena triangularis (Herbst, 1799)) represent a different phenological pattern with immature animals overwintering and becoming mature in the spring. In addition, there are some families with a multiannual life cycle and overlapping generations (Hillyard 2005, Curtis \& Machado 2007).

Beyond that, the ecology of harvestmen in the boreonemoral context is still poorly known. Heinäjoki (1944), Stol (2003) and Uddström et al. (2013) summarized the knowledge for Nordic countries, while Spungis (2008) provided an account for Latvia. In addition to the species composition, all authors briefly discussed habitat preference. Comments about the ecology of harvestmen in south-western Finland were provided by Hippa (1975). However, at least in the Baltic region, there is still lack of systematic data on distribution and abundance which would enable to analyse e.g. habitat preference of these arach- nids. Compared to pitfall traps and handpicking, which are mostly used in studies of harvestmen diversity (e.g. Stol 2003, Prasifka et al. 2007), Malaise traps may also render valuable data suitable for quantitative analysis (Hicks et al. 2003).

Today, Malaise traps, introduced by a Swedish entomologist R. E. Malaise (Malaise 1937), are widely used for monitoring insect diversity. Currently, the best known activity in Europe is probably the Swedish Malaise Trap Project, in which 61 Townes type traps were operated throughout the country in 44 collecting localities from 2003 to 2006 (Karlsson et al. 2005, Ronquist 2010). As a result of mainly that initiative, the list of Swedish insects has recently grown by about 1,900 species including hundreds of them new to science (Ronquist 2010). Inspired by the Swedish accomplishment, and being supported by the Estonian Environmental Board, an analogous trapping project was initiated in Estonia in 2008, with more than 0.7 million specimens collected this far (see Soon et al. 2012, for an example). In addition to insects, Arachnida including 
Table 1. Sampling localities and periods of the Estonian Malaise Trap Project.

\begin{tabular}{|c|c|c|c|c|}
\hline $\begin{array}{l}\text { Site } \\
\text { no. }\end{array}$ & $\begin{array}{l}\text { Site name/ } \\
\text { county }\end{array}$ & $\begin{array}{l}\text { Latitude/ } \\
\text { longitude }\end{array}$ & Biotope & Sampling periods \\
\hline 1 & $\begin{array}{l}\text { Viidumäe/ } \\
\text { Saare }\end{array}$ & $\begin{array}{l}58^{\circ} 17^{\prime} 37^{\prime \prime} \mathrm{N} \\
23^{\circ} 05^{\prime} 21^{\prime \prime} \mathrm{E}\end{array}$ & $\begin{array}{l}\text { Edge of a } \\
\text { spring fen }\end{array}$ & $\begin{array}{l}\text { 05.V.-22.XI.2009 } \\
\text { 02.VIII.-27.X.2010 } \\
\text { 23.VI.-26.XI.2011 }\end{array}$ \\
\hline 2 & $\begin{array}{l}\text { Orissaare/ } \\
\text { Saare }\end{array}$ & $\begin{array}{l}58^{\circ} 33^{\prime} 19^{\prime \prime} \mathrm{N} \\
23^{\circ} 05^{\prime} 12^{\prime \prime} \mathrm{E}\end{array}$ & $\begin{array}{l}\text { Patch of deciduous } \\
\text { managed forest in } \\
\text { an urban area }\end{array}$ & $\begin{array}{l}\text { 15.VII.-19.XI.2008 } \\
\text { 12.IV.-10.XI.2009 } \\
\text { 26.VI.-15.XI.2010 } \\
\text { 08.V.-20.XI.2011 }\end{array}$ \\
\hline 3 & $\begin{array}{l}\text { Igaküla/ } \\
\text { Saare }\end{array}$ & $\begin{array}{l}58^{\circ} 36^{\prime} 03^{\prime \prime} \mathrm{N} \\
23^{\circ} 07^{\prime} 42^{\prime \prime} \mathrm{E}\end{array}$ & $\begin{array}{l}\text { Pine forest } \\
\text { with Corylus }\end{array}$ & $\begin{array}{l}\text { 15.VII.-19.XI.2008 } \\
\text { 12.IV.-10.XI.2009 } \\
\text { 26.VI.-15.XI.2010 } \\
\text { 07.V.-20.XI.2011 }\end{array}$ \\
\hline 4 & $\begin{array}{l}\text { Kerema/ } \\
\text { Hiiu }\end{array}$ & $\begin{array}{l}58^{\circ} 53^{\prime} 26^{\prime \prime} \mathrm{N} \\
22^{\circ} 56^{\prime} 52^{\prime \prime} \mathrm{E}\end{array}$ & $\begin{array}{l}\text { Moist alvar grassland } \\
\text { with juniper brush }\end{array}$ & $\begin{array}{l}\text { 14.VIII.-23.XI.2008 } \\
\text { 05.IV.-21.XI.2009 } \\
\text { 30.VI.-9.XII.2010 } \\
\text { 10.V.-27.XI.2011 }\end{array}$ \\
\hline 5 & $\begin{array}{l}\text { Üksnurme/ } \\
\text { Harju }\end{array}$ & $\begin{array}{l}59^{\circ} 17^{\prime} 42^{\prime \prime} \mathrm{N} \\
24^{\circ} 37^{\prime} 41^{\prime \prime} \mathrm{E}\end{array}$ & $\begin{array}{l}\text { Unmanaged old } \\
\text { apple orchard next to } \\
\text { cultivated grassland }\end{array}$ & $\begin{array}{l}\text { 17.VIII.-30.XI.2008 } \\
\text { 11.IV.-14.XI.2009 } \\
\text { 11.VII.-31.X.2010 } \\
\text { 08.VII.-01.XII.2011 }\end{array}$ \\
\hline 6 & $\begin{array}{l}\text { Kunila/ } \\
\text { Lääne }\end{array}$ & $\begin{array}{l}58^{\circ} 37^{\prime} 51^{\prime \prime} \mathrm{N} \\
23^{\circ} 48^{\prime} 38^{\prime \prime} \mathrm{E}\end{array}$ & $\begin{array}{l}\text { Moist broad-leaved } \\
\text { forest }\end{array}$ & $\begin{array}{l}\text { 15.VII.-19.XI.2008 } \\
\text { 06.IV.-26.X.2009 } \\
\text { 25.VI.-16.XI.2010 } \\
\text { 08.V.-23.XII.2011 }\end{array}$ \\
\hline 7 & $\begin{array}{l}\text { Tõstamaa/ } \\
\text { Pärnu }\end{array}$ & $\begin{array}{l}58^{\circ} 20^{\prime} 10^{\prime \prime} \mathrm{N} \\
24^{\circ} 00^{\prime} 23^{\prime \prime} \mathrm{E}\end{array}$ & $\begin{array}{l}\text { Next to brush covered } \\
\text { ditch bank surrounded } \\
\text { by fallow grassland }\end{array}$ & $\begin{array}{l}\text { 15.VII.-17.XI.2008 } \\
\text { 10.IV.-17.X.2009 } \\
\text { 25.VI.-14.XI.2010 } \\
\text { 09.V.-07.XI.2011 }\end{array}$ \\
\hline 8 & $\begin{array}{l}\text { Nigula NR/ } \\
\text { Pärnu }\end{array}$ & $\begin{array}{l}58^{\circ} 00^{\prime} 24^{\prime \prime} \mathrm{N} \\
24^{\circ} 42^{\prime} 44^{\prime \prime} \mathrm{E}\end{array}$ & $\begin{array}{l}\text { Paludified pine } \\
\text { forest with } \\
\text { Polytrichum }\end{array}$ & $\begin{array}{l}\text { 14.VII.-20.XI.2008 } \\
\text { 09.IV.-04.XI.2009 } \\
\text { 25.VI.-30.XI.2010 } \\
\text { 08.V.-14.XI.2011 }\end{array}$ \\
\hline 9 & $\begin{array}{l}\text { Tõramaa/ } \\
\text { Pärnu }\end{array}$ & $\begin{array}{l}58^{\circ} 25^{\prime} 52^{\prime \prime} \mathrm{N} \\
25^{\circ} 02^{\prime} 39^{\prime \prime} \mathrm{E}\end{array}$ & Flooded meadow & $\begin{array}{l}\text { 19.VIII.-21.XI.2008 } \\
\text { 27.IV.-23.XI.2009 } \\
\text { 21.VII.-09.XI.2010 } \\
\text { 22.V.-06.XI.2011 }\end{array}$ \\
\hline 10 & $\begin{array}{l}\text { Mäetaguse/ } \\
\text { Ida-Viru }\end{array}$ & $\begin{array}{l}59^{\circ} 13^{\prime} 38^{\prime \prime} \mathrm{N} \\
27^{\circ} 19^{\prime} 12^{\prime \prime} \mathrm{E}\end{array}$ & Sparse oak forest & $\begin{array}{l}\text { 19.VIII.-02.XI.2008 } \\
\text { 06.V.-21.X.2009 } \\
\text { 01.VII.-04.X.2010 } \\
\text { 01.VI.-24.X.2011 }\end{array}$ \\
\hline 11 & $\begin{array}{l}\text { Pataste/ } \\
\text { Jõgeva }\end{array}$ & $\begin{array}{l}58^{\circ} 34^{\prime} 52^{\prime \prime} \mathrm{N} \\
26^{\circ} 46^{\prime} 42^{\prime \prime} \mathrm{E}\end{array}$ & $\begin{array}{l}\text { Moist forest dominated } \\
\text { by alder, birch, } \\
\text { bird cherry and spruce }\end{array}$ & $\begin{array}{l}\text { 07.VIII.-18.XI.2008 } \\
\text { 19.IV.-07.XI.2009 } \\
\text { 10.VII.-18.X.2010 } \\
\text { 15.V.-15.XII.2011 }\end{array}$ \\
\hline 12 & $\begin{array}{l}\text { Maiorg/ } \\
\text { Tartu }\end{array}$ & $\begin{array}{l}58^{\circ} 16^{\prime} 41^{\prime \prime} \mathrm{N} \\
26^{\circ} 20^{\prime} 03^{\prime \prime} \mathrm{E}\end{array}$ & $\begin{array}{l}\text { Spruce and aspen } \\
\text { dominated old forest } \\
\text { along a rivulet valley }\end{array}$ & $\begin{array}{l}\text { 06.VIII.-01.XI.2008 } \\
\text { 18.IV.-08.XI.2009 } \\
\text { 28.VI.-07.XI.2010 } \\
\text { 01.V.-30.X.2011 }\end{array}$ \\
\hline 13 & $\begin{array}{l}\text { Sudaste/ } \\
\text { Tartu }\end{array}$ & $\begin{array}{l}58^{\circ} 19^{\prime} 43^{\prime \prime} \mathrm{N} \\
26^{\circ} 56^{\prime} 25^{\prime \prime} \mathrm{E}\end{array}$ & $\begin{array}{l}\text { Oxalis-type drained } \\
\text { spruce forest }\end{array}$ & $\begin{array}{l}\text { 04.VIII.-16.XI.2008 } \\
\text { 19.IV.-08.XI.2009 } \\
\text { 02.V.-06.XI.2010 } \\
\text { 30.IV.-12.XI.2011 }\end{array}$ \\
\hline 14 & $\begin{array}{l}\text { Puka/ } \\
\text { Valga }\end{array}$ & $\begin{array}{l}58^{\circ} 02^{\prime} 25^{\prime \prime} \mathrm{N} \\
26^{\circ} 12^{\prime} 24^{\prime \prime} \mathrm{E}\end{array}$ & $\begin{array}{l}\text { Edge of plaudified } \\
\text { forest; Filipendula } \\
\text { type }\end{array}$ & $\begin{array}{l}\text { 10.VIII.-13.XI.2008 } \\
\text { 18.IV.-21.XI.2009 } \\
\text { 04.VII.-28.XI.2010 } \\
\text { 21.V.-20.XI.2011 }\end{array}$ \\
\hline 15 & $\begin{array}{l}\text { Leoski/ } \\
\text { Võru }\end{array}$ & $\begin{array}{l}57^{\circ} 42^{\prime} 35^{\prime \prime} \mathrm{N} \\
27^{\circ} 08^{\prime} 19^{\prime \prime} \mathrm{E}\end{array}$ & $\begin{array}{l}\text { Edge of dry boreal forest; } \\
\text { Vaccinum myrtillus } \\
\text { type }\end{array}$ & $\begin{array}{l}\text { 10.VIII.-11.XI.2008 } \\
\text { 24.IV.-17.XI.2009 } \\
\text { 11.VII.-04.XII.2010 } \\
\text { 19.V.-23.X.2011 }\end{array}$ \\
\hline
\end{tabular}


Fig. 2. - a. Rebuilt collecting head $(A$, upper container; B, connecting ring; $\mathrm{C}$, collecting bottle with preserving liquid). - b. Sorted material stored at $20^{\circ} \mathrm{C}$. -c. $40 \mathrm{ml}$ and $20 \mathrm{ml}$ containers for storing of material in alcohol. - d. A trap in Viidumäe (Site 1). - e. A trap in Tõramaa (Site 9). - f. A trap in Üksnurme (Site 5). - g. A trap in Kunila (Site 6).

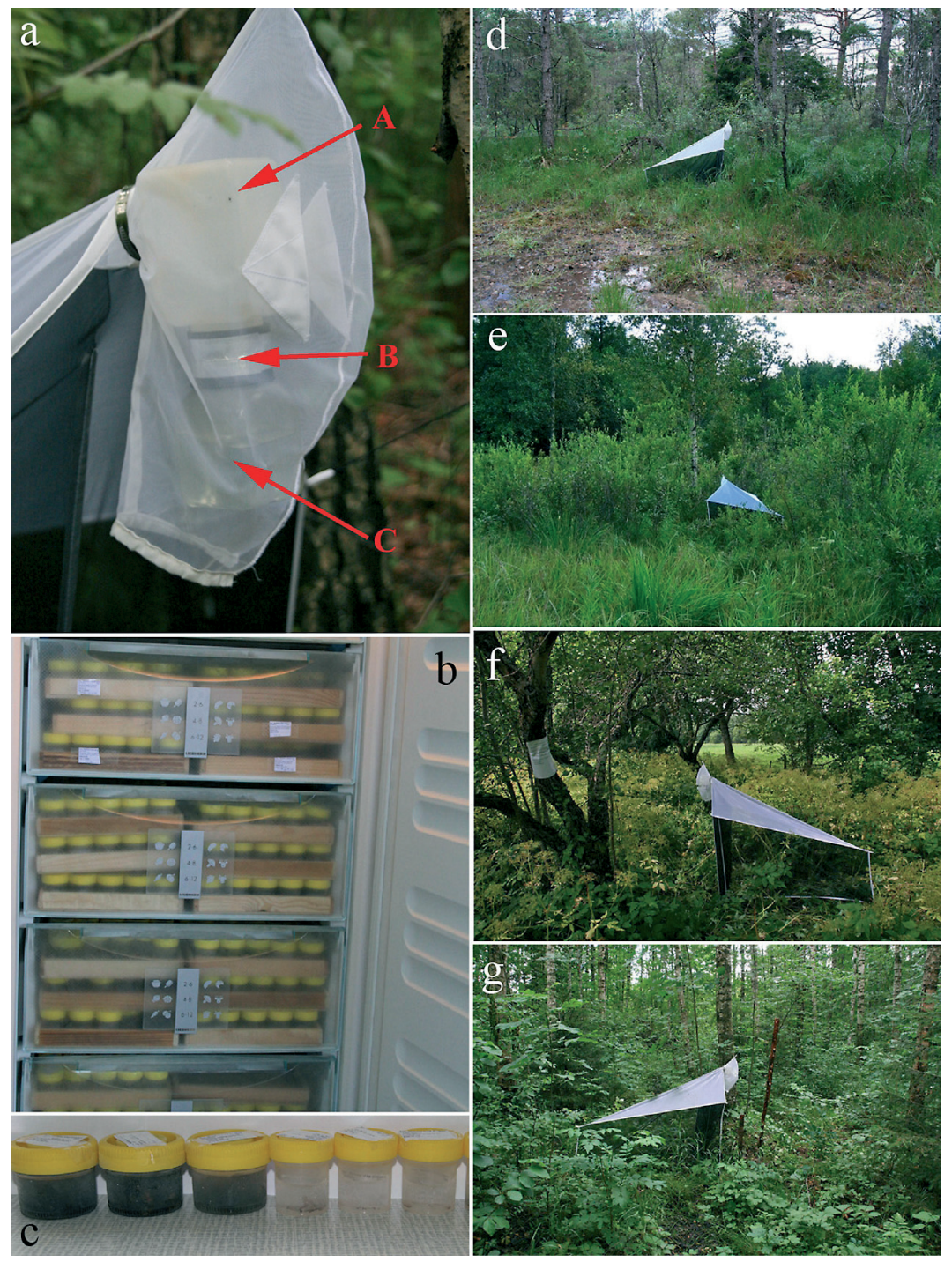

Opiliones were collected in considerable numbers, facilitating quantitative studies to be performed.

The first and so far still the most thorough study on Estonian harvestmen dates back to 1859 when A. E. Grube listed 11 species mainly from Livonia, a historical administrative unit comprising northern Latvia and southern Estonia. Of these species, seven were supplemented by locality information from the present-day Estonia. Thereafter, Chevrizov (1979a) listed, without providing any particular data, seven species of Opiliones as living in Estonia, six of these not covered by Grube (1859). Spungis (2008) re- ported only four species from Estonia, in contrast to 15 species currently known from Finland (Uddström et al. 2013) and 16 from Latvia (Spungis 2008). Notably, none of these earlier reports have been supported by data on voucher specimens. The clearly incomplete and even controversial character of the information indicates the need for a critical revision of Estonian opilionid fauna.

The aim of the present communication is: (1) to provide a critical account of previously published records on Estonian harvestmen, (2) to report original faunistic data based on the results of the Estonian Malaise Trap Project with present- 
ing new country records, accompanied by voucher specimens data and (3) to analyse habitat preference of the collected species. In addition, an opportunity has been taken to give a short overview on the Estonian Malaise Trap Project (below as EMTP) which aims at discovering undocumented arthropods of Estonian biota.

\section{Material and methods}

\subsection{Collecting and preserving}

All the original material studied was collected within the framework of the EMTP carried out during the four years from 2008 to 2011. The "Czech type" traps purchased from Ento Sphinx (see http://www.entosphinx.cz/) were set out at 15 different localities covering most of the country (Fig. 1 and Table 1), and were operated for several months in each season. The intention was to cover a wide range of habitats (Fig. 2d-g, Table $1)$.

The original mesh-based collecting heads of the traps were reconstructed and replaced by a setup made of two plastic containers (Fig. 2a), typical of Townes type traps. The $300 \mathrm{ml}$ collecting bottle of each Malaise trap was filled with preserving liquid: $70 \%$ ethyl alcohol with addition of about $5 \%$ ethylene glycol to hinder the evaporation of alcohol. All traps were served by a local operator and checked every two weeks, when the collecting bottle with the material was replaced. Upon collection, the liquid was percolated from the bottle and pure $96 \%$ ethyl alcohol added followed by storing the bottles with the material at about $-20^{\circ} \mathrm{C}$. All the material was accumulated in Tartu where it was sorted down to selected groups: mainly to the order level but in case of Hymenoptera and Diptera also to groups of lower levels. Altogether more than 700,000 specimens of arthropods were sorted to 9,935 groups (= twoweeks samples per locality) which are currently stored in $96 \%$ ethyl alcohol at $-20^{\circ} \mathrm{C}$ temperature: each sample separately in 20 or $40 \mathrm{ml}$ polypropylene container (see Fig. 2b, c). The preserving method used generally conserves DNA well over long periods of time (Nagy 2010), thereby making the samples potentially useful for DNA analyses of Estonian arthropods in future.
Table 2. Vegetation variables recorded for the study sites with the range of possible values, 0 : nearly absent, 1: sparse, 2: dense and 3: very dense. The number in the brackets shows the number of sites characterised by a particular value.

\begin{tabular}{lllll}
\hline Variable & \multicolumn{3}{l}{ Value } \\
\hline Density: & & & & \\
$\quad$ Herbaceous layer & $0(2)$ & $1(5)$ & $2(4)$ & $3(4)$ \\
$\quad$ Shrub layer & $0(3)$ & $1(3)$ & $2(8)$ & $3(1)$ \\
$\quad$ Tree layer & $0(0)$ & $1(6)$ & $2(9)$ & $3(0)$ \\
Coniferous (C) & & & \\
or decidous trees (D) & C (2) & D (6) & C and D (7)
\end{tabular}

In total, 4102 specimens of Opiliones were sorted out and identified under a stereomicroscope Olympus SZ40 using identification keys by Hillyard (2005), Chevrizov (1979b) and Martens (1978). All the determined material is still deposited in alcohol in the insect collection of the Institute of Agricultural and Environmental Sciences, Estonian University of Life Sciences (former Institute of Zoology and Botany), Tartu, Estonia (IZBE). The voucher specimens data - at least one individual per locality - listed below have also been added to the Estonian biodiversity database (Abarenkov et al. 2010, see also http:// elurikkus.ut.ee/index.php?lang=eng).

\subsection{Analysis of habitat preference}

To characterize distribution and habitat preferences of harvestmen in Estonia, the quantitative data yielded by the EMTP were subjected to an explorative analysis of associations between the occurrence of opilionids, and environmental parameters. For each study site, along with geographical coordinates, several variables characterising vegetation structure were recorded (Table 2) and used as explanatory variables in the models.

In species-specific analyses, we used either abundance (number of specimens collected, for the three most abundant species) or occurrence (as a binary trait: species present or absent, for four less abundant species) as the response variables; two species were too rare for a meaningful analysis. Accordingly, the models fitted were either mixed linear models (for abundance; SAS PROC MIXED, SAS Institute Inc. 2008), or 
Table 3. Abundance (three most common species), occurrence (four less common species), species richness and diversity (Shannon index, H') of harvestmen explained by (generalized) linear models. A site*year observation was treated as an independent data point, site was included in the model as a random factor. Full models were fitted first, a backward elimination procedure was performed until only significant $(\alpha=0.05)$ effects remained in the definitive model. See text for details. Abbreviations: O. tri: O. tridens, M. mor. M. morio, L. tis: $L$. tisciae, L. eph: L. ephippiatus, R. tri: R. triangularis, L. pal: L. palpinalis, P. opi: P. opilio.

\begin{tabular}{|c|c|c|c|c|c|c|c|c|c|}
\hline & \multicolumn{3}{|c|}{ Abundance } & \multicolumn{4}{|c|}{ Occurrence } & \multirow{2}{*}{$\begin{array}{l}\text { Species } \\
\text { richness }\end{array}$} & \multirow[t]{2}{*}{ Diversity } \\
\hline & O. tri & M. mor & L. tis & L. eph & R. tri & L. pal & P. opi & & \\
\hline Latitude & $\mathrm{ns}$ & ns & $\mathrm{ns}$ & $\mathrm{ns}$ & $\mathrm{ns}$ & ns & $\mathrm{ns}$ & $\mathrm{ns}$ & ns \\
\hline Longitude & ns & ns & ns & ns & ns & $+* * *$ & ns & ns & ns \\
\hline Year & ns & ns & ns & (ns) & ns & ns & ns & ** & ns \\
\hline Grass $^{a}$ & $\mathrm{~ns}$ & ns & ns & ns & $\mathrm{ns}$ & $\mathrm{ns}$ & (ns) & ns & $\mathrm{ns}$ \\
\hline Shrub $^{a}$ & ns & ns & ns & ns & ns & ns & ns & ns & ns \\
\hline $\operatorname{Tree}^{\mathrm{a}}$ & $+* *$ & $+* \star$ & $+* *$ & ns & ns & $t^{\star *}$ & $-^{*}$ & $+^{\star *}$ & $+^{\star \star * *}$ \\
\hline Forest type ${ }^{b}$ & ns & ns & ns & ns & ns & ns & (ns) & ns & ns \\
\hline Start day & $\mathrm{ns}$ & ns & $\mathrm{ns}$ & $--^{\star *}$ & $--^{\star *}$ & $\mathrm{~ns}$ & ns & $\mathrm{ns}$ & $-^{\star *}$ \\
\hline
\end{tabular}

a: layer density (Table 2).

b: coniferous or deciduous trees (Table 2 ).

ns: $p>0.05,{ }^{*}: p<0.05,{ }^{* *}: p<0.01,{ }^{* * *}: p<0.001$.

(ns): respective factor was not included in the model for computational reasons (iterations failed to converge) but one-way analyses suggested no effect.

+ : positive effect of a continuous vatriable, - : negative effect of a continuous variable.

mixed generalized linear models (for occurrence; SAS PROC GLIMMIX). The values of the response variables for a particular site in a particular year were treated as independent observations. The analyses were thus run with 57 data points (15 sites $\times 4$ years, with 3 observations missing). In all analyses, study site was treated as a random factor, which, in combination with the Kenward-Roger method (Kenward \& Roger 1997) of estimation of denominator degrees of freedom $(d d f)$, ensured that the number of $d d f$ was not inflated as a consequence of repeated measurements (i.e., four years of recording) on one particular site. The values of "abundance" were $\log (\mathrm{x}+1)$ transformed to meet the assumptions of GLM.

We first fitted full models with 8 independent variables (Table 3 ). In addition to longitude, latitude, year of observations (4-level categorical variable) and the four variables describing vegetation structure (Table 2), calendar date on which the observations had been started on each occasion was included as a covariate. The latter was done to correct for a possible influence of the timing of the observation period which varied among the sites and years. In most cases, the traps had been set up well before the activity period of har- vestmen, with some exceptions (Table 1). Thereafter, a "backward" simplification procedure of the models was performed: non-significant effects were removed from the models one-by-one, starting with the least significant one, so that only statistically significant effects were retained in the definitive models.

As one-figure descriptions of opilionid fauna, we used species richness (number of species) and diversity, the latter as Shannon index (eq. 1) (Magurran 2004),

$H^{\prime}=\Sigma\left(p_{i}\right)\left(\log _{2} p_{i}\right)$

in which $p_{i}$ is the relative abundance of $i^{\text {th }}$ species, calculated for each site*year replicate.

These measures were analysed as dependent on environmental variables in the same way as the species-specific abundances (see above). The values of the Shannon index were $\log (\mathrm{x}+1)$ transformed to meet the assumptions of GLM.

\section{Annotated species list}

In the following list, all species known to occur in Estonia are included with an extract of literature 
Table 4. Number of individuals collected within the Estonian Malaise Trap Project and the Shannon Index ( $\left.\mathrm{H}^{\prime}\right)$ for each location (see Fig. 1, Table 1). For species name abbreviations see Table 3, except for N. lug: N. lugubre, O. din: O. dinaricus.

\begin{tabular}{|c|c|c|c|c|c|c|c|c|c|c|}
\hline \multirow{2}{*}{$\begin{array}{l}\text { Site } \\
\text { no. }\end{array}$} & \multicolumn{8}{|c|}{ Number of collected individuals } & \multirow[b]{2}{*}{ L. tis } & \multirow{2}{*}{$\begin{array}{l}\text { Shannon } \\
\text { Index }\end{array}$} \\
\hline & N.Iug & P. opi & O. din & R. tri & L. pal & O. $t r i$ & L. eph & M. mor & & \\
\hline 1 & 1 & 3 & & & & 3 & & 6 & 1 & 1.40 \\
\hline 2 & & & & 16 & & 77 & 11 & 291 & 18 & 0.91 \\
\hline 3 & & & & & & 208 & 1 & 267 & 56 & 0.96 \\
\hline 4 & & 2 & & 1 & & 20 & & 104 & 15 & 0.83 \\
\hline 5 & & 3 & & 1 & & 32 & 2 & 22 & 3 & 0.88 \\
\hline 6 & & & & & 2 & 74 & 1 & 224 & 18 & 0.79 \\
\hline 7 & & 42 & & 3 & & 24 & & & 11 & 1.09 \\
\hline 8 & & & & 2 & 8 & 22 & 1 & 33 & 1 & 1.19 \\
\hline 9 & 2 & & & & & & & 4 & & 0.63 \\
\hline 10 & & & & 8 & 3 & 116 & & & & 0.34 \\
\hline 11 & & & & 2 & 4 & 182 & 2 & 340 & 116 & 1.07 \\
\hline 12 & & & & 14 & 5 & 146 & 3 & 102 & 136 & 1.28 \\
\hline 13 & 1 & & & 25 & 8 & 169 & 13 & 252 & 108 & 1.32 \\
\hline 14 & 1 & & & 4 & 7 & 100 & 4 & 21 & 11 & 1.10 \\
\hline 15 & & 1 & 4 & 13 & 12 & 158 & 6 & 321 & 48 & 1.15 \\
\hline
\end{tabular}

data on their distribution, habitat and diet. In addition to species recorded by the Estonian Malaise trap project, three species, viz. Opilio parietinus (De Geer, 1778), Lacinius horridus (Panzer, 1794) and Leiobunum rotundum (Latreille, 1798), are included on the basis of literature reports. If not otherwise stated, the global distribution is presented according to Martens (1978). An asterisk (*) before the species name indicates a new species to Estonia. The number of collected specimens per species per locality are presented in Table 4.

\subsection{Nemastomatidae}

\subsubsection{Nemastoma lugubre (Müller, 1776)}

Estonian sources. Grube 1859: 41, as Naemastoma bimaculatum (Fabr.) from Heiligensee [Pühajärve], Kamby [Kambja], Tabbifer [Tabivere], Nurmis [Nurme near Otepää]; Chevrizov 1979a: 427, from Estonia; Spungis 2008: 22, from Estonia (by M. Martin comments as $N$. bimaculatum).

Voucher material. Valgamaa, Puka, 5802'25”'N 2612'24”'E, 05.-25.X.2008, J. Viidalepp leg. [IZBE0300008]; Pärnumaa, Tõra- maa, 58 $25^{\prime} 52^{\prime \prime}$ N 2502'39” E, 12.-27.X.2009, A. Martsoo leg. [IZBE0300018]; Saaremaa,

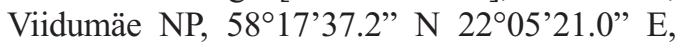
30.VIII.-14.IX.2009, T. Talvi leg. [IZBE03000 26]; Tartumaa, Sudaste, $58^{\circ} 19^{\prime} 43.8^{\prime \prime}$ N 26 $6^{\circ} 56^{\prime}$ 25.1” E, 23.VIII.-05.IX.2009, O. Kurina leg. [IZBE0300058].

Distribution. The western distribution limit of the species lies in eastern France and Belgium and the species reaches western Russia and northern Scandinavia in the east (Lehtinen 1964) but is absent from the British Isles.

Biology. In terms of habitat use, N. lugubre is not a particularly demanding species. Two main criteria of habitat selection are sufficient, namely soil moisture and shadiness, although Lehtinen (1964) observed that acid soils are avoided by the species. Deciduous forests are most suitable for this species but it can occur in other types of forests, as well as in more open areas (Martens 1978, Spungis 2008). The species is rarely found above ground layer (Todd 1949, Martens 1978). Known food items are mites and highly putrescent wood (Acosta \& Machado 2007 and references therein).

Remarks. Nemastoma lugubre is very similar to the closely related $N$. bimaculatum (Fabricius, 1775). The latter is known to be distributed only 
in central and western parts of Europe and on British Isles while $N$. lugubre occurs from central to eastern Europe (Martens 1978). Therefore, it is most likely that Grube's (1859) reports of $N$. bimaculatum actually refer to $N$. lugubre (see also Spungis 2008, for discussion). The low numbers of $N$. lugubre in Malaise traps probably reflect the selectivity of the traps used. In particular, $N$. lugubre is a small species, it is rarely seen above the ground layer and the animals are thus unlikely to crawl up into the trap's container.

\subsection{Phalangiidae}

\subsubsection{Phalangium opilio Linnaeus, 1761}

Estonian sources. Spungis 2008: 22, from Estonia (referred to as M. Martin, per. comm.).

Voucher material. Saaremaa, Viidumäe NP, 58 17'37.2” N 2205’21.0” E, 14.-27.IX.2009, T. Talvi leg. [IZBE0300025]; Hiiumaa, Kerema, $58^{\circ} 53$ '26.5” N 22 $566^{\prime} 52.5$ ” E, 29.VII.-14.VIII. 2010, R. Miller leg. [IZBE0300031]; Harjumaa, Üksnurme near Saku, 59¹7'42.5” N 2437' 41.1" E, 25.VII.-08.VIII.2009, E. Ilumäe leg. [IZBE0300032]; Võrumaa, Leoski near Haanja, 5742’35.1” N 2708'19.8” E, 03.VIII-28.IX. 2009, A. Saarnits leg. [IZBE0300049]; Pärnumaa, Tõstamaa, 58 20'10.4” N 2400'23.6” E, 24.VIII.-07.IX.2009, E. Liiv leg. [IZBE030 0040].

Distribution. This is a widely distributed Palaearctic species which has also been introduced to North America and New Zealand.

Biology. Phalangium opilio has a clear preference to open habitats which is rare among harvestmen. The species can be found in gardens and parks (often on tree trunks and walls), and in hedgerows, fields, grassland and open woodland (e.g. Martens 1978, Spungis 2008). It is an active forager (Edgar \& Yuan 1968), for instance, Morse (2001) observed it trying to steal a spider's prey. The diet of the species is diverse, including beetles, gastropods and other harvestmen (Bristowe 1949, Sankey 1949, Todd 1950). In laboratory studies, Edgar (1971) observed a specimen eating its own eggs.

Remarks. Grube (1859: 41) listed the species as Phalangium cornutum L. Herm. but without any particular locality data, and therefore, this record cannot be reliably associated with Estonia.

\subsubsection{Opilio dinaricus Silhavý, 1938}

Estonian sources. Chevrizov 1979a: 429, from Estonia.

Voucher material. Võrumaa, Leoski near Haanja, 5742’35.1' N 2708'19.8' E, 28.IX.15.X.2009, A. Saarnits leg. [IZBE0300048].

Distribution. The distribution covers mostly mountainous districts in central, south and eastern Europe. The largest known continuous distribution area surrounds the Eastern Alps and continues in the Dinaric Alps. The species is also distributed in Latvia (Spungis 2008).

Biology. The species has a preference for forests with a lush herbaceous layer near water bodies (Martens 1978). Mitov and Stoyanov (2005) specified that forest habitats around mountain ranges are clearly preferred at least in Bulgaria. Opilio dinaricus has also been found in the city of Sofia and its surroundings (Mitov \& Stoyanov 2004) but according to Martens (1978) it is an unusual habitat for the species.

\subsubsection{Opilio parietinus (De Geer, 1778)}

Estonian sources. Grube 1859: 40, as Opilio parietinus Herbst from Dorpat [Tartu]; Spungis 2008: 22, from Estonia (referred to as M. Martin, per. comm.).

Distribution. Originating from the Near East and Mediterranean region, the species is now very common throughout Western Palaearctic. It is distributed also in North America and Tasmania.

Biology. In Central Europe, the species inhabits mainly anthropogenic habitats including large cities, e.g. central London (Martens 1978, Hillyard 2005). The association with human influenced areas seems to grow stronger as the climate becomes less favourable: in Middle East $O$. parietinus lives in natural habitats as well (Martens 1978). Known food items are millipedes, aphids, spiders and fish remains (Sankey 1949, Dixon \& McKinlay 1989).

Remarks. Opilio leucophaeus Koch, treated as synonym of Mitopus morio by Grube (1859), is today considered to be conspecific with $O$. 
parietinus (e.g. Delfosse 2004). It is somewhat surprising that no specimens of $O$. parietinus were collected by the EMTP even if its range covers most of the Western Palaearctic (Martens 1978), including Latvia and Finland. However, the species is considered highly synanthropic, therefore its preferred habitats include urban areas like parks and gardens (Bristowe 1949, Martens 1978, Hillyard 2005, Spungis 2008), which were poorly represented in the EMTP. Hence, the selectivity of the Malaise trap towards $O$. parietinus remains unclear.

\subsubsection{Rilaena triangularis (Herbst, 1799)}

Estonian sources. Grube 1859: 41, as Platybunus denticornis from Heligensee [Pühajärve].

Voucher material. Valgamaa, Puka, $58^{\circ} 02^{\prime}$ 25” N 26¹2'24" E, 05.-19.VII.2009, J. Viidalepp leg. [IZBE0300005]; Saaremaa, Orissaare, 5833'19.4” N 2305'12.7” E, 26.VI.-11.VII. 2010, H. Jäe leg. [IZBE0300017]; Ida-Virumaa, Mäetaguse, 59¹3’38.6” N 27¹9'12.9” E, 03.17.VI.2009, H. Aia leg. [IZBE0300021]; Hiiumaa, Kerema, 58 53'26.5”N 22 56 ' $52.5^{\prime}$ ” E, 20.IV.-07.V.2009, R. Miller leg. [IZBE03000 29]; Harjumaa, Üksnurme near Saku, 59¹7'42.5” N 2437'41.1' E, 25.VII.-08.VIII. 2009, E. Ilumäe leg. [IZBE0300034]; Pärnumaa, Tõstamaa, $58^{\circ} 20^{\prime} 10.4^{\prime \prime}$ N24ㅇ'23.6” E, 12.25.VI.2009, E. Liiv leg. [IZBE0300038]; Jõgeva, Pataste, 58 34'52.2” N 2646'42.3” E, 31.V.16.VI.2009, J. Elts leg. [IZBE0300045]; Võrumaa, Leoski near Haanja, 5742'35.1” N 2708'19.8” E, 25.VI.-14.VII.2009, A. Saarnits leg. [IZBE0300055]; Tartumaa, Sudaste, 58 19'43.8” N2656'25.1” E, 02.-17.V.2009, O. Kurina leg. [IZBE0300060]; Tartumaa, Maiorg near Annikoru, 58 16'41.6" N 26²0'3.6” E, 14.-28.VI.2009, O. Kurina leg. [IZBE0300064]; Pärnumaa, Nigula NR, 58 00'24" N 2442'44" E, 25.VI.-12.VII.2010, K. Kübar leg. [IZBE0300074]; Läänemaa, Kunila near Lihula, $58^{\circ} 37^{\prime} 51.1 ” \quad \mathrm{~N} \quad 23^{\circ} 48^{\prime} 38.5 ”$ E, 19.VI.03.VII.2011, R. Nikkel leg. [IZBE0300077].

Distribution. The species is widely distributed from western Europe to western Russia and has also been introduced to North America.

Biology. The species occurs typically in moist mixed, deciduous and spruce forests. It is rare in open habitats like fields and dry grasslands but has also been found in gardens (Bristowe 1949, Martens 1978, Hillyard 2005). Rilaena triangularis usually stays on the ground or in the shrub layer but sometimes also migrates up to tree trunks (Todd 1949, Martens 1978). The known food objects include isopods and other harvestmen (Sankey 1949, Sunderland \& Sutton 1980). This is one of the few European species which overwinters in the nymph stage (not as eggs) and matures in spring (Martens 1978, Hillyard 2005).

\section{*3.2.5. Lophopilio palpinalis (Herbst, 1799)}

Voucher material. Valgamaa, Puka, 58 $02^{\prime} 25^{\prime \prime} \mathrm{N}$ 2612'24” E, 27.X.-21.XI.2009, J. Viidalepp leg. [IZBE0300004]; Ida-Virumaa, Mäetaguse, 59¹3'38.6” N 2719'12.9' E, 22.VIII.-05.IX. 2011, H. Aia leg. [IZBE0300022]; Võrumaa, Leoski near Haanja, 5742’35.1' N 2708'19.8' E, 03.VIII.-28.IX.2009, A. Saarnits leg. [IZBE0300052]; Tartumaa, Sudaste, 58 $19^{\circ}$ 43.8” N 2656'25.1” E, 18.X.-08.XI.2009, O. Kurina leg. [IZBE0300062]; Tartumaa, Maiorg near Annikoru, 58 $16^{\prime} 41.6$ " N 26²0’3.6” E, 19.IX.-04.X.2009, O. Kurina leg. [IZBE03000 65]; Pärnumaa, Nigula NR, 58 $00^{\prime} 24^{\prime \prime} \mathrm{N}$ 2442'44” E, 24.IX.-09.X.2009, K. Kübar leg. [IZBE0300071]; Läänemaa, Kunila near Lihula, 58³7'51.1” N 2348'38.5” E, 11.-25.IX.2011, R. Nikkel leg. [IZBE0300075].

Distribution. Lophopilio palpinalis is distributed from central Europe to eastern France, southern Scandinavia and Southwest of Bulgaria (Martens 1978, Stol 2003). It has also been recorded from Latvia (Spungis 2008) and Finland (Uddström et al. 2013).

Biology. As a hygrophilous species, floors of different types of moist forests are preferred as habitats. However, in central and western Europe, the species inhabits also more open areas, such as fields, meadows or even gardens (Todd 1949, Martens 1978, Hillyard 2005, Spungis 2008). In addition to typical soft bodied prey, L. palpinalis has also been seen consuming juices of a mushroom (Adams 1984, Acosta \& Machado 2007 and references therein). 


\subsubsection{Oligolophus tridens (C. L. Koch, 1836)}

Estonian sources. Chevrizov 1979a: 429, from Estonia.

Voucher material. Valgamaa, Puka, $58^{\circ} 02$ '25” N 2612'24” E, 23.X.-06.XI.2011, J. Viidalepp leg. [IZBE0300002]; Saaremaa,

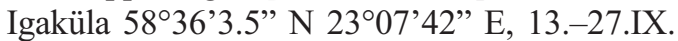
2009, H. Jäe leg. [IZBE0300009]; Saaremaa, Orissaare, 58 $33^{\prime} 19.4^{\prime \prime} \mathrm{N} \quad 2^{\circ} 05^{\prime} 12.7^{\prime \prime}$ E, 22.VIII.-05.IX.2010, H. Jäe leg. [IZBE03000 15]; Ida-Virumaa, Mäetaguse, 59¹3'38.6" N 27¹9'12.9” E, 12.-26.VIII.2009, H. Aia leg. [IZBE0300020]; Saaremaa, Viidumäe NP, $58^{\circ} 17^{\prime} 37.2^{\prime \prime} \quad \mathrm{N} \quad 22^{\circ} 05^{\prime} 21.0^{\prime \prime}$ E, 30.VIII.14.IX.2009, T. Talvi leg. [IZBE0300023]; Hiiumaa, Kerema, 58 53'26.5” N 22 56 '52.5” E, 26.X.-08.XI.2009, R. Miller leg. [IZBE03000 27]; Harjumaa, Üksnurme near Saku, 59॰17'42.5” N 2437'41.1” E, 31.X.-14.XI. 2009, E. Ilumäe leg. [IZBE0300036]; Pärnumaa, Tõstamaa, 58²0'10.4” N 240'23.6” E, 02.17.X.2009, E. Liiv leg. [IZBE0300039]; Jõgevamaa, Pataste, 58 34'52.2" N 2646'42.3" E, 25.VIII.-06.IX.2009, J. Elts leg. [IZBE03000 43]; Võrumaa, Leoski near Haanja, 5742’35.1" N 2708'19.8” E, 14.VII.-03.VIII.2009, A. Saarnits leg. [IZBE0300054]; Tartumaa, Sudaste, 58 $19^{\prime} 43.8^{\prime \prime} \mathrm{N}$ 2656’25.1” E, 20.IX.-04.X. 2009, O. Kurina leg. [IZBE0300059]; Tartumaa, Maiorg near Annikoru, 58 16'41.6”' N 2620' 3.6” E, 05.-19.IX.2009, O. Kurina leg. [IZBE03 00067]; Pärnumaa, Nigula NR, 5800'24” N 2442'44”'E, 27.VIII.-06.IX.2009, K. Kübar leg. [IZBE0300073]; Läänemaa, Kunila near Lihula, 58 37'51.1"N 2348'38.5” E, 14.-28.VIII.2011, R. Nikkel leg. [IZBE0300076].

Distribution. Oligolophus tridens is a widely distributed Holarctic species.

Biology. Mixed deciduous and spruce forests are preferred but otherwise the species dwells in different habitats with sufficient soil moisture, e. g. humid meadows and agricultural fields. Specimens are mainly found on the ground layer but may be also observed moving in shrubs and bushes (Todd 1949, Martens 1978, Hillyard 2005, Spungis 2008, Mihal \& Gajdoš 2010). Oligolophus tridens is known to consume plant matter in addition to the typical food objects of harvestmen (see M. morio for details). Bristowe
(1949) recorded "a pellet of vegetable matter" and "the inside of a nutty seed" as consumed by the species. The food records also include a bird dropping, dead vertebrates and other harvestmen as prey (Bristowe 1949, Sankey 1949, Todd 1950).

\subsubsection{Lacinius ephippiatus (C. L. Koch, 1835)}

Estonian sources. Grube 1859: 40, as Acantholophus ephippiatus from Arrol [Arula near Otepää]; Spungis 2008: 22, from Estonia (referred to as M. Martin, per. comm.).

Voucher material. Valgamaa, Puka, 5802'25” N 26¹2'24” E, 02.-16.VIII.2009, J. Viidalepp leg. [IZBE0300006]; Saaremaa, Igaküla, 58 $36^{\prime} 3.5^{\prime \prime} \mathrm{N} 23^{\circ} 07^{\prime} 42^{\prime \prime}$ E, 22.VIII.05.IX.2010, H. Jäe leg. [IZBE0300012]; Saaremaa, Orissaare, 58³3'19.4” N 2305'12.7' E, 08.-22.VIII.2010, H. Jäe leg. [IZBE0300014]; Harjumaa, Üksnurme near Saku, 59¹7'42.5” N 2437’41.1” E, 22.VIII.-05.IX.2009, E. Ilumäe leg. [IZBE0300035]; Jõgevamaa, Pataste, 58 34'52.2” N 2646'42.3” E, 13.-26.VII.2009, J. Elts leg. [IZBE0300044]; Võrumaa, Leoski

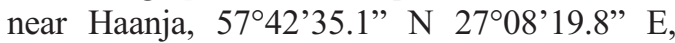
14.VII.-03.VIII.2009, A. Saarnits leg. [IZBE03 00050]; Tartumaa, Sudaste, 58 $19^{\circ} 43.8^{\prime \prime} \mathrm{N}$ 265'25.1” E, 11.-26.VII.2009, O. Kurina leg. [IZBE0300057]; Tartumaa, Maiorg near Annikoru, 58 $16^{\circ} 41.6^{\prime \prime} \mathrm{N} 26^{\circ} 20^{\prime} 3.6^{\prime \prime} \mathrm{E}, 26$.VII.08.VIII.2009, O. Kurina leg. [IZBE0300066]; Pärnumaa, Nigula NR, 58 $00^{\circ} 24^{\prime \prime} \mathrm{N} 24^{\circ} 42^{\prime} 44^{\prime}$ " E, 09.-24.VII.2009, K. Kübar leg. [IZBE0 300069].

Distribution. The species occurs from southern Europe (except Mediterranean areas) to central Scandinavia (Heinäjoki 1944, Uddström et al. 2013).

Biology. A hygrophilous species, preferring forests with sufficient soil moisture and lush herbaceous layer according to Martens (1978). However, the species may also be found on forest floor covered with leaf litter (Adams 1984). In the case of sufficient relative humidity, more open habitats, e. g. fields and meadows, can also be inhabited (Todd 1949, Martens 1978, Hillyard 2005, Spungis 2008). The diet includes typical, small soft-bodied prey (Sunderland \& Sutton 1980, Adams 1984). 


\subsubsection{Lacinius horridus (Panzer, 1794)}

Estonian sources. Chevrizov 1979a: 428, from Estonia.

Distribution. The species is common in southern Europe but it is also distributed in Latvia and southern Finland (Martens 1978, Stol 2003, Spungis 2008, Uddström et al. 2013).

Biology. Being one of the few thermophilous species of harvestmen (Martens (1978), L. horridus prefers open habitats, e.g. dry grasslands, sparse and warm forests, and some anthropogenic biotopes (Martens 1978, Mitov \& Stoyanov 2005).

Remarks. Grube (1859: 40) listed the species as Phalangium hispidum Herbst but without any collecting locality data and therefore, this record cannot be reliably associated with Estonia. However, we credit hereby the Chevrizov's (1979a) record as the species has a unique appearance and a misidentification is unlikely. In Latvia, Spungis (2008) found it only from coastal sand dunes in the Southwestern part of the country, and thus, the warm coastal regions of Estonia should be further studied.

\subsubsection{Mitopus morio (Fabricius, 1779)}

Estonian sources. Grube 1859: 41, as Opilio grossipes from Arrol [Arula near Otepää].

Voucher material. Läänemaa, Kunila, 583' 51.1" N 2348'38.5” E, 03.-17.VII.2011, R. Nikkel leg. [IZBE0300078]; Valgamaa, Puka, 5802'25” N2612’24” E, 13.-27.IX.2009, J. Viidalepp leg. [IZBE0300007]; Saaremaa, Igaküla, 58 36’3.5” N 2307'42” E, 16.-30.VIII. 2009, H. Jäe leg. [IZBE0300010]; Saaremaa, Orissaare, 58 $33^{\prime} 19.4^{\prime \prime} \mathrm{N} 23^{\circ} 05^{\prime} 12.7^{\prime}$ ' E, 18.X.02.XI.2010, H. Jäe leg. [IZBE0300013];

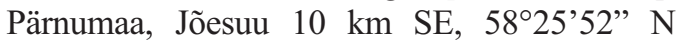
2502’39” E, 20.VII.-03.VIII.2009, A. Martsoo leg. [IZBE0300019]; Saaremaa, Viidumäe NP, 58`17’37.2” N2205'21.0” E, 14.-27.IX.2009, T. Talvi leg. [IZBE0300024]; Hiiumaa, Kerema, $58^{\circ} 53$ '26.5” N 22॰56'52.5” E, 26.IX.-10.X. 2009, R. Miller leg. [IZBE0300028]; Harjumaa, Üksnurme near Saku, 59¹7'42.5” N 24³7'41.1" E, 31.X.-14.XI.2009, E. Ilumäe leg. [IZBE0300033]; Jõgevamaa, Pataste, 58³4' 52.2” N 2646’42.3” E, 13.-26.VII.2009, J. Elts leg. [IZBE0300046]; Võrumaa, Leoski near

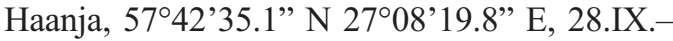
15.X.2009, A. Saarnits leg. [IZBE0300053]; Tartumaa, Sudaste, 58 $8^{\circ} 19^{\prime} 43.8^{\prime \prime}$ N 26 $56^{\circ} 25.1$ " E, 09.-23.VIII.2009, O. Kurina leg. [IZBE0 300061]; Tartumaa, Maiorg near Annikoru, 58 16'41.6” N 26²0'3.6” E, 23.VII.-05.VIII. 2010, O. Kurina leg. [IZBE0300068]; Pärnumaa, Nigula NR, 5800'24” N 2442'44'E, 06.24.IX.2009, K. Kübar leg. [IZBE0300072].

Distribution. Mitopus morio is a common and remarkably widespread Holarctic species. It is distributed in Greenland and up to the Arctic Ocean in Fennoscandia (e.g. Lehtinen 1964).

Biology. The species has diverse habitat preferences including different types of mixed, deciduous and coniferous woodlands (Martens 1978, Tchemeris et al. 1998), moist meadows (Tchemeris et al. 1998, Spungis 2008), marshes (Todd 1949), different cultural landscapes (Martens 1978) and even potato fields (Dixon \& McKinlay 1989). The species does not seem to eat any plant matter (Phillipson 1960, Adams 1984). Generally, small soft bodied living or recently dead arthropods are preferred which is common among opilionids (Phillipson 1960, Adams 1984). In addition, as observed by Bristowe (1949), the prey includes other harvestmen, too.

Remarks. Chevrizov (1979a) did not specifically mention the species' occurrence in Estonia, but he referred to it as a widely distributed species in the European part of the former USSR. Mitopus morio shows a considerable intraspecific variation in colour pattern (Hillyard 2005), hence the numerous specific names have been introduced for describing different colour forms of the species, most of them having been synonymised afterwards (Hillyard 2005, Kury 2010).

\subsection{Sclerosomatidae}

\subsubsection{Leiobunum rotundum (Latreille, 1798)}

Estonian sources. Grube 1859: 41, as Opilio hemisphaericus Hbst. from Kamby [Kambja] and Nurmis [Nurme near Otepää].

Distribution. The species is widely distributed in northern, central and western Europe, but absent from the Mediterranean region. 
Biology. Leiobunum rotundum is a highly eurytopic species, although more forested habitats are preferred (Spoek 1963, Martens 1978, Spungis 2008). It inhabits parks, gardens and different kinds of forests. Known diet includes spiders, isopods, gastropods, earthworms, dead vertebrates and various insects (Bristowe 1949, Sankey 1949, Todd 1950, Adams 1984, Dixon \& McKinlay 1989).

\section{*3.3.2. Leiobunum tisciae Avram, 1968}

Voucher material. Valgamaa, Puka, 58 02 '25” N 2612'24”'E, 27.IX.-11.X.2009, J. Viidalepp leg. [IZBE0300003 ]; Saaremaa, Igaküla, 58³6’3.5" N 2307'42”'E, 27.IX.-12.X.2009, H. Jäe leg. [IZBE0300011]; Saaremaa, Orissaare, 58 33' 19.4” N 2305'12.7” E, 08.-22.VIII.2010, H. Jäe leg. [IZBE0300016]; Hiiumaa, Kerema, 58 53'26.5” N 22 56'52.5” E, 31.VIII.-14.IX. 2010, R. Miller leg. [IZBE0300030]; Pärnumaa, Tõstamaa, 58²0'10.4” N2400'23.6” E, 17.31.X.2010, E. Liiv leg. [IZBE0300041]; Harjumaa, Üksnurme near Saku, 59 $17^{\prime} 42.5^{\prime}$ N 243'ㄴ⒈1” E, 03.-17.X.2009, E. Ilumäe leg. [IZBE0300037]; Jõgevamaa, Pataste, 58³4' 52.2" N 2646'42.3” E, 20.IX.-05.X.2009, J. Elts leg. [IZBE0300047]; Võrumaa, Leoski near Haanja, 5742'35.1” N 2708'19.8” E, 15.X.03.XI.2009, A. Saarnits leg. [IZBE0300051]; Tartumaa, Sudaste, 58¹9'43.8' N 2656'25.1'" E, 23.VIII.-05.IX.2009, O. Kurina leg. [IZBE03 00056]; Tartumaa, Maiorg near Annikoru, 58 16'41.6” N 26²0'3.6” E, 22.VIII.-05.IX. 2009, O. Kurina leg. [IZBE0300063]; Pärnumaa, Nigula NR, 58 00 '24” N 2442'44” E, 24.IX.09.X.2009, K. Kübar leg. [IZBE0300070].

Distribution. The species is distributed in middle and eastern Europe (Martens 1978), including the southern part of Finland (Uddström et al. 2013).

Biology. According to Martens (1978, pers. comm. to KT), the species prefers anthropogenic habitats like gardens and parks in the Baltic region. However, according to our results, the species was abundant also in natural habitats.

Remarks. The species is very close to $L$. rupestre (Herbst, 1799) which has been reported to occur in Estonia by Chevrizov (1979a: 428). However, according to recent information (Mar- tens pers. comm. to $\mathrm{KT}$ ), L. rupestre is only distributed in the Alps and some mountains of SW Germany. Thus, the earlier records of L. rupestre in Central and Eastern Europe may actually represent L. tisciae. Consequently, and because there is no supporting voucher material, we do not include L. rupestre to the Estonian list.

\section{Species richness and diversity}

The sampling in a dry boreonemoral forest at Leoski (Site 15, Fig. 1) resulted in highest species richness (8 species), followed by sites in a paludified forest at Puka (Site 14) and drained spruce forest at Sudaste (Site 13). All these sites are located in southern Estonia. However, Shannon's index (Table 4) was highest in a spring-fed fen in Viidumäe (Site 1), resulting in the highest total species diversity, although only 14 specimens were collected from that site. Only 6 specimens from 2 species were caught from a flooded meadow at Toramaa (Site 9), which may refer to the poor suitability of the habitat for harvestmen in general. Another site showing a low species richness was a sparse oak forest in Mäetaguse (Site 10), whereas a strong dominance of one species (O. tridens) was also evident there.

Two species were much less abundant than the others: $O$. dinaricus, represented by four specimens, was collected from Leoski only, while five specimens of $N$. lugubre were caught from four sites (see Table 4 for details). Low numbers of the latter may be explained by the unsuitability of Malaise trapping for this species, due to the fact that $N$. lugubre rarely leaves the ground layer (Todd 1949, Martens 1978).

\section{Habitat preference}

Previous studies of harvestmen's habitat preference (e.g. Hippa 1975, Stol 2003, Spungis 2008, Mihal \& Gajdoš 2010, Uddström et al. 2013) have relied on samples caught by pitfall traps, sieving and haphazard handpicking. Although Malaise traps have claimed not to be particularly effective in collecting harvestmen (e.g. Smith et al. 2006), our long-term trapping yielded a data set complete enough for a quantitative analysis. For the three most common species, viz. O. tri- 
dens, M. morio and L. tisciae, site-specific abundance was shown to be associated to tree layer density only: the animals were clearly more numerous in closed forests, as compared to more open landscapes (Table 3). The same was true for the occurrence of L. palpinalis. Consistently, species richness and Shannon index were higher in the forests. Interestingly, there were no associations of other vegetation parameters to any of the species, neither was there an association of latitude. Longitude attained significance in one species with an eastern distribution (L. palpinalis). However, the values of tree layer density were correlated with those of latitude and grass cover across the study sites $\left(r_{S}=+0.51\right.$ and -0.52 , respectively), and may have masked each other. To control for this potential problem, tree layer density was replaced either by "latitude" or "grass cover" in alternative versions of the definitive models (Table 2). Even if these variables sometimes attained significance in such models, the AIC values for the models including "tree layer density" instead of "latitude" or "grass cover" were invariably lower, so we stick to the interpretation that it was forest closeness, and not latitude or grass cover which most probably affected distribution patterns of harvestmen. We inspected visually the distribution of residuals from each of the definitive models, and found no evidence of spatial autocorrelation (formal tests of SAC were not considered meaningful given the moderate sample size), there was thus no need for spatially explicit regression methods (Beale et al. 2010).

In conclusion, with respect to habitat preferences in Estonia, harvestmen showed to be generalists with their populations being associated only to tree layer density, i.e. the presence of forest as such. Our results are consistent with those by Curtis and Machado (2007) who showed the median richness of harvestmen in forests to be 2.8 times higher than in open habitats around the world. In Norway, Stol (2003) showed deciduous wood to be preferred by most harvestmen species, whereas we did not find any significant differences between the types of the forest. The reportedly higher habitat specificity of harvestmen in more southern parts of Europe (e.g. Hillyard 2005) may be related to the low suitability of too hot conditions for these animals. If the avoidance of xerothermic habitats is the primary driver of the habitat preference, the generalism of these animals at more northern latitudes is easy to understand.

As a methodological contribution, our results show that long-term Malaise trapping is a sufficient method to collect harvestmen inhabiting tree- and shrub layers of forests. Nevertheless, the scarcity of $N$. lugubre and the absence of $M$. chrysomelas from our catches may be related to low effectiveness of Malaise traps to detect the presence of the species of the debris layer. A complete study of harvestmen species richness may thus require a combined application of Malaise and pitfall traps.

\section{Species possibly occurring in Estonia}

In addition to 12 Estonian species listed and discussed above, some of the following species can possibly occur in the country.

Mitostoma chrysomelas (Hermann, 1804) is found in Latvia (Spungis 2008) and the southern part of Sweden (Stol 2003), although Spungis (2008) suggests the northern limit of the species' distribution lies in Latvia. Nevertheless, due to the selectivity of Malaise traps, the occurrence of the species in Estonia cannot be entirely excluded.

Both Oligolophus hanseni (Kraepelin, 1896) and Opilio saxatilis C.L. Koch, 1839 are distributed in Latvia (Spungis 2008) and Finland (Uddström et al. 2013) which suggests they could also be found in Estonia.

Nelima gothica Lohmander, 1945 seems to prefer coastal habitats (Hillyard 2005) and as it is distributed in southern Finland (Ilvessalo 1981), the occurrence of the species in Estonia is possible.

The highly invasive species Opilio canestrinii (Thorell, 1876) has recently been collected from Finland (Uddström et al. 2013) so it may be expected to invade Estonia as well.

Grube (1859) listed also Gyas annulatus (Olivier, 1792) [as Phalangium bicolor Fabr.] but without any locality name. This species, shown to be endemic to the Alps (Martens 1978), is not referred to by any subsequent authors, and is consequently excluded from the Estonian list. 
Acknowledgements. The study was supported by Estonian Science Foundation grant 9174, institutional financing project IUT21-1 and by the European Union through the European Regional Development Fund (Center of Excellence FIBIR). The Estonian Environmental Board is acknowledged for financing the EMTP (2008-2011). We thank all co-workers who participated in the EMTP and made this research possible. We are grateful to Prof. Dr. Jochen Martens, Dr. Lars Friman and Veikko Rinne who kindly shared their knowledge and assisted with the identifications.

\section{References}

Abarenkov, K., Tedersoo, L., Nilsson, R. H., Vellak, K., Saar, I., Veldre, V., Parmasto, E., Prous, M., Aan, A., Ots, M., Kurina, O., Ostonen, I., Jõgeva, J., Halapuu, S., Põldmaa, K., Toots, M., Truu, J., Larsson, K.-H., Kõljalg, U. 2010: PlutoF - a web based workbench for ecological and taxonomic research, with an online implementation for fungal ITS sequences. - Evolutionary Bioinformatics 6: 189-196. doi:10.4137/EBO. S6271

Acosta, L. E. \& Machado, G. 2007: Diet and Foraging. In: Pinto-da-Rocha, R., Machado, G. \& Giribet, G. (eds.), Harvestmen: The Biology of Opiliones: 309338. Cambridge, Massachusetts, and London, England: Harvard University Press. 597 pp.

Adams, J. 1984: The Habitat and Feeding Ecology of Woodland Harvestmen (Opiliones) in England. - Oikos 42: 361-370.

Beale, C. M., Lennon, J. J., Yearsley, J. M., Brewer, M. J., Elston, D. A. 2010: Regression analysis of spatial data. — Ecology Letters 13 (2): 246-264. doi: 10.1111/ j.1461-0248.2009.01422.x

Bristowe, W. S. 1949: The distribution of harvestmen (Phalangida) in Great Britain and Ireland, with notes on their names, enemies and food. - Journal of Animal Ecology 18:100-114.

Chevrizov, B. P. 1979a: On the fauna of Opiliones of the western regions of the European part of the USSR. Revue d'Entomologique de l'URSS 58, No. 2: 426430. [In Russian].

Chevrizov, B. P. 1979b: A brief key to the harvest spiders (Opiliones) of the European territory of the USSR. Trudy Zoologicheskogo Instituta Akademii Nauk SSSRTrudy Zool. Inst. AN SSSR, Leningrad 85: 427. [In Russian].

Curtis, D. J. \& Machado, G. 2007: Ecology. — In: Pintoda-Rocha, R., Machado, G. \& Giribet, G. (eds.), Harvestmen: The Biology of Opiliones: 280-308. Cambridge, Massachusetts, and London, England: Harvard University Press. 597 pp.

Delfosse, E. 2004: Catalogue préliminaire des Opilions de France métropolitaine (Arachnida, Opiliones). Bulletin de Phyllie 20: 34-58.

Dixon, P. L. \& McKinlay, R. G. 1989: Aphid predation by harvestmen in potato fields in Scotland. - Journal of Arachnology 17: 253-255.
Edgar, A. L. \& Yuan, H. A. 1968: Daily Locomotory Activity in Phalangium opilio and Seven Species of Leiobunum (Arthropoda:Phalangida). — Bios 4: 167-176.

Edgar, A. L. 1971: Studies on the biology and ecology of Michigan Phalangida (Opiliones). — Miscellaneous Publications. Museum of Zoology, University of Michigan 144: 1-64.

Grube, A. E. 1859: Verzeichniss der Arachnoiden Liv-, Kur- und Ehstlands. - Archiv für die Naturkunde Liv-, Ehst- und Kurlands 2(1): 417-486.

Heinäjoki, M. 1944: Die Opilionidenfauna Finnlands. Acta Zoologica Fennica 42: 3-26. [In German].

Hicks, B. J., McKenzie, F., Cosens, D., \& Watt, A. D. 2003: Harvestmen abundance and diversity within lodgepole and Scots pine plantations of Scotland and their impact on pine beauty moth populations. - Forest ecology and management 182: 355-361.

Hillyard, P. D. 2005: Harvestmen. - Shrewsbury: Field Studies Council for The Linnean Society of London and The Estuarine and Coastal Sciences Association. $167 \mathrm{pp}$.

Hippa, H. 1975: Faunistic and Ecological Notes on the Opilionid Fauna (Opilionida) of South-West Häme, Finland. - Lounais-Hämeen Luonto 55: 1-4.

Ilvessalo, I. 1981: Opilionida Nelima Gothica Lohmander, Suomelle uusi lukkilaij (Phalangiidae). - Notulae Entomologicae 61: 228. [in Finnish]

Karlsson, D., Pape, T., Johanson, K. A. Liljeblad, J., Ronquist, F. 2005: The Swedish Malaise trap project, or how many species of Hymenoptera and Diptera are there in Sweden. - Entomologosk Tidskrift 126(12): 43-53. [In Swedish].

Kenward, M. G. \& Roger, J. H. 1997: Small sample inference for fixed effects from restricted maximum likelihood. - Biometrics 53(3): 983-997.

Kury, A. B. 2010: Opilionological Record - a chronicle of harvestman taxonomy. Part 1: 1804-1758. — Journal of Arachnology 38: 521-529.

Kury, B. 2011: Order Opiliones Sundevall, 1833. - In: Zhang, Z.-Q. (ed.), Animal biodiversity: An outline of higher-level classification and survey of taxonomic richness. - Zootaxa 3148: 112-114.

Lehtinen, P. T. 1964: The Phalangids and Pseudoscorpionids of Finnish Lapland. - Reports from the Kevo Subarctic Research Station 1: 279-287.

Magurran, A. E. 2004: Measuring Biological Diversity. Oxford, Blackwell Publishing. 215 pp.

Malaise, R. 1937: A new insect trap. — Entomologisk Tidskrift 58: 148-160.

Martens, J. 1978: Spinnentiere, Arachnida: Weberknechte, Opiliones. Die Tierwelt Deutschlands, vol. 64. Gustav Fisher, Jena. 464 pp.

Mihal, I. \& Gajdoš, P. 2010: Harvestmen (Arachnida, Opiliones) with notes on their habitat requirements in selected areas of Central Slovakia. - Folia Oecologica 2: 205-210.

Mitov, P. G. \& Stoyanov, I. L. 2004: The harvestmen fauna (Opiliones, Arachnida) of the city of Sofia (Bulgaria) and its adjacent regions. - In: Penev, L., Niemelä, J., Kotze, D. J. \& Chipev, N. (eds.), Ecology of the City of 
Sofia. Species and Communities in an Urban Environment: 319-354. Pensoft, Sofia-Moscow.

Mitov, P. G. \& Stoyanov, I. L. 2005: Ecological profiles of harvestmen (Arachnida, Opiliones) from Vitosha Mountain (Bulgaria): a mixed modelling approach using gams. - Journal of Arachnology 33: 256-268.

Morse, D. H. 2001: Harvestmen as commensals of crab spiders. - Journal of Arachnology 29: 273-275.

Nagy, Z. T. 2010: A hands-on overview of tissue preservation methods for molecular genetic analyses. - Organisms Diversity \& Evolution 10(1): 91-105.

Phillipson, J. 1960: A Contribution to feeding biology of Mitopus morio (F) (Phalangida). - Journal of Animal Ecology 29: 35-43.

Prasifka, J. R., Lopez, M. D., Hellmich, R. L., Lewis, L. C., \& Dively, G. P. 2007: Comparison of pitfall traps and litter bags for sampling ground dwelling arthropods. - Journal of Applied Entomology 131: 115-120.

Ronquist, F. 2010: 250 Years of Swedish Taxonomy. — In: Polaszek, A. (ed.), Systema Naturae 250 - The Linnaean Ark: 241-252. CRS Press. 300 pp.

Sankey, J. H. P. 1949: Observations on food, enemies and parasites of British harvestspiders (Arachnida: Opilioncs). - Entomologist's Monthly Magazine 85: 246-247.

SAS Institute Inc. 2008. SAS/STAT® 9.2 User Guide. Cary, NC: SAS Institute Inc.

Smith, R. M., Warren, P. H., Thompson, K. \& Gaston, K. J. 2006: Urban domestic gardens (VI): environmental correlates of invertebrate species richness. - In: Hawksworth, D. L. \& Bull, A. T. (eds.), Human Exploitation and Biodiversity Conservation: 75-98. Springer. 512 pp.

Soon, V., Kesküla, T. \& Kurina, O. 2012: Strepsiptera spe- cies in Estonia. - Entomologica Fennica 22 (2011): 213-218.

Spoek, G. L. 1963: The Opilionida (Arachnida) of the Netherlands. - Zoologische Verhandelingen 63: 1-70.

Spungis, V. 2008: Fauna, Distribution, Habitat Preference and Abundance of Harvestmen (Opiliones) in Latvia. - Latvijas entomologs 45: 14-24.

Stol, I. 2003: Distribution and ecology of harvestmen (Opiliones) in the Nordic countries. - Norwegian Journal of Entomology 50: 33-42.

Stol, I. 2007: Checklist of Nordic Opiliones. - Norwegian Journal of Entomology 54: 23-26.

Sunderland, K. D. \& Sutton, S. L. 1980: A serological study of arthropod predation on woodlice in a dune grassland ecosystem. - The Journal of Animal Ecology 49: 987-1004.

Tanhuanpää, M., Ruohomäki, K. \& Kaitaniemi, P. 2003: Influence of adult and egg predation on reproductive success of Epirrita autumnata (Lepidoptera: Geometridae). - Oikos 102: 263-272.

Tchemeris, A. N., Logunov, D. V. \& Tsurusaki, N. 1998: A contribution to the knowledge of the harvestman fauna of Siberia (Arachnida: Opiliones). — Arthropoda Selecta 7: 189-199.

Todd, V. 1949: The habits and ecology of the British harvestmen (Arachnida: Opiliones) with special reference to those of the Oxford district. - Journal of Animal Ecology 18: 209-229.

Todd, V. 1950: Prey of Harvestmen (Arachnida, Opiliones). - Entomologist's Monthly Magazine 86: 252 254.

Uddström, A., Rinne, V. \& Pajunen. T. 2013: Opiliones new to Finland and an updated checklist. - Memoranda pro Societas Fauna et Flora Fennica 89: 1-3. 